\title{
Estimation of Genetic Variability and Heritability in Selected Mulberry Germplasm Accessions (Morus spp.)
}

\author{
Suraksha Chanotra*, Ramesh Kumar Bali and Kamlesh Bali
}

Division of Sericulture, SKUAST-J, Chatha, India

*Corresponding author

\begin{tabular}{|l|}
\hline Ke y w o r d s \\
Mulberry, PCV, \\
GCV, Variability, \\
Heritability, \\
Characterization \\
\hline Article Info \\
\hline $\begin{array}{l}\text { Accepted: } \\
\text { 07 January } 2019 \\
\text { Available Online: } \\
\text { 10 February } 2019\end{array}$ \\
\hline
\end{tabular}

\section{A B S T RA C T}

Genetic variability analysis and heritability of different yield contributing characters were investigated in 44 mulberry genotypes for six morphological and eight physiological traits to understand the available genetic variability for future improvement of mulberry. Phenotypic coefficient of variation (PCV \%) was found to be higher than the respective genotypic coefficient of variation (GCV \%) for all the characters denoting variability among genotypes. Estimates of phenotypic and genotypic coefficient of variation were high for fresh leaf weight $(39.72,35.06 \%)$ moderate for other traits $(10-30 \%)$ and least in moisture percentage $(9.24,6.81 \%$ respectively). High genetic advance coupled with heritability was observed in the characters namely, fresh leaf weight $(77.9 \%)$, followed by number of leaves per meter twig (68.6\%), internodal distance (64.4\%), leaf length $(61.4 \%)$, dry leaf weight, moisture percentage $(54.3 \%)$ and actual leaf area $(48.2 \%)$ and least in leaf width $(36.7 \%)$. High genetic advance coupled with high heritability revealed significant contribution of fresh leaf weight among studied components. The study revealed importance of agro-morphological traits in characterization of germplasm accessions and in selection for future breeding programmes.

\section{Introduction}

Mulberry is the primary host of silkworms (Bombyx mori L.), which belongs to family Moraceae and it is exploited on a commercial scale for silk production. It is a perennial plant belonging to the genus Morus of family Moraceae, division Magnoliophyta, class Magnoliopsida falling under order Urticales. The origin of mulberry is Asia. The original home of the genus is lower Himalayan belt of Indo-China. Genus Morus has 68 recognized species available in different parts of the world, of which 35 species are found in Asia and 14 in continental America. Sericulture and silk production is directly correlated with production of high quality mulberry leaves. Hence, development of improved mulberry varieties with high leaf productivity and quality is essential for horizontal and vertical growth of sericulture in the country.

Breeding activities aiming towards increase in productivity can benefit from a thorough understanding of the genetic variability and diversity within a set of germplasm 
accessions. Genetic variability is the prerequisite for initiation of any crop improvement programme including mulberry and selection acts upon the variability which is present in the genotypes. The precise information on the nature and degree of genetic diversity helps the plant breeder in choosing the diverse parents for purposeful hybridization. Genetic variation is also fundamental for species conservation to meet present and future requirement. The extent of magnitude of genetic variability in the mulberry germplasm helps in the crop improvement through conventional breeding. For making effective selection based on the metric traits estimation of genetic variability parameters heritability and genetic advance indicates the extent of trait transmissibility generation to generation. Hence, in the present investigation foliage yield and some important growth traits of indigenous and exotic accessions of mulberry was carried out to determine genetic variability among 44 mulberry genotypes conserved in the germplasm bank of SKUAST-J.

\section{Materials and Methods}

\section{Experimental site and material}

The present study was conducted at the Mulberry Germplasm Bank, Udheywalla campus, Sher-e-Kashmir University of Agricultural Sciences and Technology of Jammu. The experimental material comprised of 44 mulberry genotypes (Table 1) maintained at of $1 \times 1$ meter spacing as bush plantation.

\section{Experimental data}

60 days mature leaves were picked up randomly for three replications for recording data. Eight quantitative traits viz., leaf length $(\mathrm{cm})$, leaf width $(\mathrm{cm})$, actual leaf area $\left(\mathrm{cm}^{2}\right)$, fresh leaf weight in g (100 leaves), dry leaf weight in $\mathrm{g}$ (100 leaves), moisture percentage, internodal distance and number of leaves per meter twig were recorded from randomly sampled replications. Leaf length and width was measured with measuring scale and actual leaf area was determined by graphical analysis. For obtaining fresh leaf weight 100, leaves were picked up randomly from selected replications and weighed immediately on electronic balance and same leaves were oven dried at $70^{\circ} \mathrm{C}$ till constant weight was achieved and again weighed on electronic balance to determine the oven dry weight. For determining number of leaves per meter twig, one meter length of each branch was measured and total number of leaves counted. Moisture content and internodal distance was calculated in percentage by using the formulas given below:

Moisture percentage $=$

Fresh leaf weight- Oven dry weight

X 100

Fresh leaf weight

Internodal distance $=\quad 100 \mathrm{~cm}$

Number of nodes

\section{Statistical analysis and estimation of genetic parameters}

The mean data of the above mentioned traits were statistically analyzed using $\mathrm{R}$ software version 3.5.1 2018 for estimation of mean square treatment, environmental variance, genotypic variance, phenotypic variance, heritability percentage, phenotypic coefficient of variation (PCV), genotypic coefficient of variation $(\mathrm{GCV})$ and genetic advance.

\section{Results and Discussion}

Results obtained for studied parameters are presented in Table 2 . The extent of variability present among the yield and yield attributes is 
presented in Table 3. A perusal of data indicated that the characters were greatly influenced by phenotypic variances and reflected impact on genotypic variances also. The analysis of genetic parameters for various quantitative traits revealed significant mean square estimates for all the characters indicating sufficient diversity among the genotypes. Mean square treatment revealed maximum value for fresh leaf weight (24071) and minimum for leaf width (5.5). This variation in genotypes is helpful in selection of superior parental material for development of promising genotypes.

Phenotypic variations were high as compared to genotypic variation for all traits under study. Genotypic variance was maximum in fresh leaf weight (7329.7) followed by actual leaf area (1781.8), dry leaf weight and moisture percentage (29.8), number of leaves per meter twig (12.1), leaf length (5.9) and internodal distance (1.7), while leaf width (1.1) showed least genotypic variance and phenotypic variations was maximum in fresh leaf weight (9411.1) followed by actual leaf area (3697.7), dry leaf weight and moisture percentage (54.9), number of leaves per meter twig (17.7), leaf length (9.7) and leaf width (3.2), while least phenotypic variance was recorded in internodal distance (2.7).

All parameters studied recorded high heritability estimates and showed high genotypic variance also. Maximum heritability percentage was observed for fresh leaf weight (77.9) whereas least heritability percentage was recorded for leaf width $(36.7 \%)$ distance indicating their reliability for effecting selection for high leaf yield parameters. Results depicted significant correlation of heritability percentage with that of genetic variance. Phenotypic coefficient of variation was more than genotypic coefficient of variation for all studied parameters. The phenotypic and genotypic coefficient of variation was high for fresh leaf weight (39.7,
$35.0 \%$ ), actual leaf area (30.2, 20.9\%), internodal distance $(29.5,23.6 \%)$, number of leaves per meter twig $(27.7,22.9 \%)$, leaf width (16.9, $10.2 \%)$, leaf length (16.7, $13.1 \%)$ and dry leaf weight $(15.8,11.7 \%)$. Lowest PCV and GCV values were recorded in moisture percentage $(9.2$ and $6.8 \%)$ respectively. High genetic advance was recorded for fresh leaf weight (63.7) followed by actual leaf area (30.0), leaf length (21.2), dry leaf weight (17.8), leaf width (12.8), moisture percentage (10.3), number of leaves per meter twig (3.9) and internodal distance (0.3).

These findings for genetic analysis of genotypes suggested greater phenotypic and genotypic variability among the accessions and sensitiveness of the attributes for making future improvement through selection. Wide differences between GCV and PCV for actual leaf area and leaf width implied its susceptibility to agro-climatic fluctuations and genetic constitution attributed for internodal distance, whereas narrow difference between GCV and PCV for other characters suggests their relative resistance to environmental alterations. PCV was higher than the respective GCV for all the characters denoting environmental factors influencing their expression to some degree or other. High estimates of genetic gain coupled with high values of GCV portrayed that these are controlled by additive genes and phenotypic selection for their improvement could be achieved by simple selection.

PCV was found to be higher than the respective GCV for all the characters denoting variability among genotypes. Estimates of phenotypic and genotypic coefficient of variation were high for fresh leaf weight $(39.72,35.06 \%)$ moderate for other traits (10-30\%) and least in moisture percentage (9.24, 6.81\% respectively) (Fig. $1)$. 
Table.1 Pedigree record of genotypes used for analysis

\begin{tabular}{|c|c|c|c|}
\hline S.No. & Name of genotype & Donor Name & Origin \\
\hline 1. & Asayuki & CSR \& TI, Mysore & Cross Pollinated Hybrid \\
\hline 2. & Enshutukasuka & CSR \& TI, Mysore & Collection \\
\hline 3. & Fukushima & CSR \& TI, Berhampore & Collection \\
\hline 4. & Goshyerami & CSR \& TI, Mysore & Selection \\
\hline 5. & Ichinose & RSRS, Kodathi & Cross Pollinated Selection \\
\hline 6. & Kairyoroso & CSR \& TI, Mysore & Cross Pollinated Hybrid \\
\hline 7. & Kamabori & CSR \& TI, Mysore & Cross Pollinated Hybrid \\
\hline 8. & Kokuso-20 & CSR \& TI, Mysore & Mutation \\
\hline 9. & Kokuso-27 & CSR \& TI, Mysore & Cross Pollinated Hybrid \\
\hline 10. & Limencina & CSR \& TI, Mysore & Collection \\
\hline 11. & Miuraso & CSR \& TI, Mysore & Collection \\
\hline 12. & Rokokyoso & RSRS, Kodathi & Clonal Selection \\
\hline 13. & Shimanouchi & CSR \& TI, Mysore & Cross Pollinated Hybrid \\
\hline 14. & BC-259 & CSR \& TI, Berhampore & Back Cross Selection \\
\hline 15. & Bhrem C-776 & CSR \& TI, Pampore & Cross Pollinated Selection \\
\hline 16. & Behrampur & CSR \& TI, Berhampore & Clonal Selection \\
\hline 17. & C-763 & CSR \& TI, Mysore & Cross Pollinated Hybrid \\
\hline 18. & Chakmajra & DOS, J\&k Govt. & Natural Selection \\
\hline 19. & Chinese white & CSR \& TI, Mysore & Collection \\
\hline 20. & Dhar local & DOS, J\&k Govt. & Open Pollinated Hybrid \\
\hline 21. & Kanva-2 & CSR \& TI, Mysore & Cross Pollinated Hybrid \\
\hline 22. & KNG & CSR \& TI, Mysore & Clonal Selection \\
\hline 23. & LF-1 & CSR \& TI, Mysore & Clonal Selection \\
\hline 24. & LF-2 & CSR \& TI, Mysore & Clonal Selection \\
\hline 25. & NS-1 & Div. of Sericulture, SKUAST-J. & Open Pollinated \\
\hline 26. & NS-2 & Div. of Sericulture, SKUAST-J. & Open Pollinated \\
\hline 27. & NS-3 & Div. of Sericulture, SKUAST-J. & Open Pollinated \\
\hline 28. & S-1 & CSR \& TI, Mysore & Clonal Selection \\
\hline 29. & S-30 & CSR \& TI, Mysore & Mutation \\
\hline 30. & S-36 & CSR \& TI, Mysore & Mutation \\
\hline 31. & S-41 & CSR \& TI, Mysore & Mutation \\
\hline 32. & S-54 & CSR \& TI, Mysore & Mutation \\
\hline 33. & S-146 & RSRS, Kodathi & Open Pollinated Selection \\
\hline 34. & S-799 & CSR \& TI, Mysore & Open Pollinated Hybrid \\
\hline 35. & S-1531 & CSR \& TI, Mysore & Open Pollinated Selection \\
\hline 36. & S-1608 & CSR \& TI, Berhampore & Open Pollinated Hybrid \\
\hline 37. & S-1635 & CSR \& TI, Berhampore & OPH Selection \\
\hline 38. & S-1708 & CSR \& TI, Berhampore & Open Pollinated Selection \\
\hline 39. & Sujanpur & DOS, J\&K Govt. & Open Pollinated Collection \\
\hline 40. & $\operatorname{Tr}-1$ & CSR \& TI, Berhampore & Colchiploid \\
\hline 41. & $\operatorname{Tr}-4$ & RSRS, Kodathi & Polyploid \\
\hline 42. & $\operatorname{Tr}-8$ & RSRS, Kodathi & Polyploid \\
\hline 43. & $\operatorname{Tr}-10$ & RSRS, Kodathi & Polyploid \\
\hline 44. & V-1 & CSR \& TI, Mysore & Cross Pollinated Hybrid \\
\hline
\end{tabular}


Table.2 Pooled mean values of eight quantitative traits of mulberry genotypes for the year 2017-18

\begin{tabular}{|c|c|c|c|c|c|c|c|c|c|}
\hline S.No. & Genotype & $\begin{array}{c}\text { Leaf } \\
\text { length } \\
(\mathrm{cm})\end{array}$ & $\begin{array}{c}\text { Leaf } \\
\text { width } \\
(\mathrm{cm})\end{array}$ & $\begin{array}{l}\text { Leaf } \\
\text { area } \\
\left(\mathrm{cm}^{2}\right)\end{array}$ & $\begin{array}{c}\text { Fresh } \\
\text { weight } 100 \\
\text { leaves }(\mathrm{g})\end{array}$ & $\begin{array}{c}\text { Dry } \\
\text { weight } \\
100 \\
\text { leaves (g) }\end{array}$ & $\begin{array}{c}\text { Leaf } \\
\text { moisture } \\
(\%)\end{array}$ & $\begin{array}{l}\text { Internodal } \\
\text { distance } \\
\text { (cm) }\end{array}$ & $\begin{array}{c}\text { Leaves/ } \\
\text { meter } \\
\text { twig (no }\end{array}$ \\
\hline 1. & Asayuki & 16.8 & 11.2 & 191.7 & 141.4 & 22.8 & 83.8 & 4.0 & 23 \\
\hline 2. & Enshutukasuka & 15.1 & 08.1 & 123.9 & 156.7 & 21.9 & 86.0 & 4.6 & 19 \\
\hline 3. & Fukushima & 19.1 & 11.1 & 213.0 & 177.5 & 20.4 & 88.5 & 3.8 & 17 \\
\hline 4. & Goshyerami & 21.8 & 12.6 & 278.0 & 240.3 & 52.4 & 78.1 & 4.6 & 17 \\
\hline 5. & Ichinose & 16.2 & 09.6 & 156.5 & 205.4 & 35.2 & 82.8 & 4.3 & 17 \\
\hline 6. & Kairyoroso & 4.8 & 09.6 & 141.0 & 102.9 & 24.2 & 76.4 & 4.5 & 18 \\
\hline 7. & Kamabori & 17.5 & 10.6 & 188.9 & 133.1 & 26.4 & 80.1 & 4.7 & 18 \\
\hline 8. & Kokuso-20 & 18.1 & 10.9 & 197.5 & 155.4 & 30.2 & 80.5 & 5.0 & 17 \\
\hline 9. & Kokuso-27 & 11.4 & 6.9 & 80.1 & 98.3 & 14.1 & 85.1 & 3.2 & 30 \\
\hline 10. & Limencina & 14.8 & 09.8 & 147.5 & 125.8 & 22.4 & 82.1 & 4.7 & 19 \\
\hline 11. & Miuraso & 19.3 & 09.3 & 181.1 & 362.4 & 69.6 & 80.7 & 6.3 & 14 \\
\hline 12. & Rokokyoso & 18.0 & 8.8 & 159.4 & 161.7 & 37.3 & 77.0 & 5.1 & 18 \\
\hline 13. & Shimanouchi & 17.6 & 12.1 & 215.7 & 149.9 & 26.2 & 82.5 & 3.4 & 19 \\
\hline 14. & BC-259 & 16.0 & 10.9 & 175.9 & 235.3 & 44.2 & 81.2 & 5.4 & 12 \\
\hline 15. & Bhrem C-776 & 19.6 & 09.7 & 190.6 & 306.8 & 42.6 & 86.1 & 9.0 & 10 \\
\hline 16. & Behrampur & 21.1 & 13.0 & 276.0 & 216.7 & 24.9 & 88.5 & 4.7 & 11 \\
\hline 17. & C-763 & 21.8 & 10.7 & 237.0 & 217.2 & 32.7 & 85.0 & 6.9 & 12 \\
\hline 18. & Chakmajra & 22.0 & 11.8 & 261.5 & 258.6 & 36.7 & 85.8 & 3.9 & 11 \\
\hline 19. & Chinese white & 19.5 & 11.1 & 222.3 & 356.9 & 64.4 & 82.0 & 7.0 & 11 \\
\hline 20. & Dhar local & 16.6 & 10.3 & 172.5 & 346.0 & 63.7 & 81.5 & 6.6 & 12 \\
\hline 21. & Kanva-2 & 18.5 & 10.4 & 195.4 & 243.5 & 77.2 & 68.2 & 5.0 & 12 \\
\hline 22. & KNG & 15.0 & 08.2 & 125.6 & 191.7 & 29.5 & 84.6 & 4.1 & 19 \\
\hline 23. & LF-1 & 16.5 & 09.9 & 163.7 & 306.1 & 84.8 & 72.2 & 4.7 & 18 \\
\hline 24. & LF-2 & 20.6 & 10.5 & 216.8 & 208.1 & 63.7 & 69.3 & 6.8 & 12 \\
\hline 25. & NS-1 & 23.2 & 11.5 & 271.6 & 232.1 & 30.5 & 86.8 & 4.8 & 12 \\
\hline 26. & NS-2 & 22.9 & 12.5 & 288.4 & 244.6 & 38.9 & 84.0 & 9.7 & 12 \\
\hline 27. & NS-3 & 18.1 & 12.0 & 218.4 & 279.1 & 48.6 & 82.5 & 5.8 & 13 \\
\hline 28. & S-1 & 17.5 & 09.1 & 161.4 & 178.9 & 31.3 & 82.5 & 5.6 & 14 \\
\hline 29. & $\mathrm{~S}-30$ & 18.1 & 10.4 & 191.8 & 266.3 & 60.0 & 77.4 & 4.7 & 15 \\
\hline 30. & S-36 & 16.8 & 09.3 & 158.3 & 233.4 & 72.2 & 69.0 & 4.9 & 15 \\
\hline 31. & S-41 & 21.7 & 11.6 & 253.4 & 322.9 & 54.7 & 83.0 & 5.2 & 13 \\
\hline 32. & S-54 & 23.3 & 12.5 & 295.0 & 400.6 & 64.1 & 84.1 & 5.1 & 17 \\
\hline 33. & S-146 & 22.2 & 12.5 & 272.6 & 299.1 & 79.8 & 73.3 & 5.6 & 14 \\
\hline 34. & S-799 & 34.8 & 08.4 & 122.4 & 126.6 & 38.6 & 69.5 & 5.0 & 13 \\
\hline 35. & S-1531 & 19.3 & 10.1 & 194.6 & 225.3 & 57.8 & 74.3 & 6.5 & 12 \\
\hline 36. & S-1608 & 21 & 09.8 & 206.6 & 341.4 & 76.2 & 77.6 & 7.1 & 13 \\
\hline 37. & S-1635 & 19.6 & 11.6 & 227.7 & 376.6 & 81.3 & 78.4 & 6.7 & 14 \\
\hline 38. & S-1708 & 19.6 & 11.7 & 233.1 & 320.1 & 31.4 & 90.1 & 7.0 & 13 \\
\hline 39. & Sujanpur & 20.6 & 11.2 & 232.0 & 246.2 & 24.9 & 89.8 & 5.6 & 11 \\
\hline 40. & $\operatorname{Tr}-1$ & 17.1 & 09.6 & 164.7 & 216.7 & 28.0 & 87.0 & 8.0 & 14 \\
\hline 41. & $\operatorname{Tr}-4$ & 18.8 & 12.1 & 228.5 & 494.8 & 91.9 & 81.4 & 7.4 & 13 \\
\hline 42. & $\operatorname{Tr}-8$ & 18.5 & 11.8 & 223.4 & 358.1 & 75.8 & 78.8 & 8.4 & 12 \\
\hline 43. & $\operatorname{Tr}-10$ & 16.0 & 10.7 & 172.3 & 153.8 & 52.6 & 65.7 & 5.8 & 13 \\
\hline 44. & $\mathrm{~V}-1$ & 20.4 & 10.3 & 212.1 & 333.2 & 47.7 & 85.6 & 6.4 & 14 \\
\hline \multicolumn{2}{|r|}{ Mean } & 18.6 & 10.6 & 201.0 & 224.1 & 46.7 & 80.2 & 5.6 & 15.2 \\
\hline \multicolumn{2}{|r|}{ S.D. } & 3.09 & 1.78 & 60.41 & 96.36 & 22.16 & 7.41 & 1.67 & 4.20 \\
\hline
\end{tabular}


Table.3 Coefficient of variations (PCV and GCV), heritability percentage and genetic advance for eight quantitative traits of 44 mulberry genotypes

\begin{tabular}{|l|l|l|l|l|l|l|l|l|l|l|l|}
\hline S.No. & Character & \multicolumn{2}{|l}{ Range } & MST & EV & GV & PV & $\begin{array}{l}\mathbf{H}^{2} \\
\mathbf{( \% )}\end{array}$ & $\begin{array}{l}\text { PCV } \\
\mathbf{( \% )}\end{array}$ & $\begin{array}{l}\text { GCV } \\
(\mathbf{\%})\end{array}$ & GA \\
\hline $\mathbf{1 .}$ & $\begin{array}{l}\text { Fresh leaf } \\
\text { weight (g) }\end{array}$ & 98.3 & 494.8 & 24071 & 2081 & 7329.7 & 9411.1 & 77.9 & 39.72 & 35.06 & 63.7 \\
\hline $\mathbf{2 .}$ & $\begin{array}{l}\text { Dry leaf } \\
\text { weight (g) }\end{array}$ & 4.1 & 91.9 & 114.7 & 25.1 & 29.8 & 54.9 & 54.3 & 15.87 & 11.70 & 17.8 \\
\hline $\mathbf{3 .}$ & $\begin{array}{l}\text { Moisture } \\
\text { content (\%) }\end{array}$ & 65.7 & 90.1 & 114.7 & 25.1 & 29.8 & 54.9 & 54.3 & 9.24 & 6.81 & 10.3 \\
\hline $\mathbf{4 .}$ & $\begin{array}{l}\text { Internodal } \\
\text { distance } \\
\text { (cm) }\end{array}$ & 3.2 & 9.7 & 6.3 & 0.9 & 1.7 & 2.7 & 64.4 & 29.50 & 23.68 & 0.3 \\
\hline $\mathbf{5 .}$ & $\begin{array}{l}\text { Leaves/m } \\
\text { (no.) }\end{array}$ & 10.0 & 30.0 & 42.1 & 5.5 & 12.1 & 17.7 & 68.6 & 27.72 & 22.95 & 3.9 \\
\hline $\mathbf{6 .}$ & $\begin{array}{l}\text { Leaf length } \\
\text { (cm) }\end{array}$ & 4.8 & 34.8 & 21.6 & 3.7 & 5.9 & 9.7 & 61.4 & 16.75 & 13.13 & 21.2 \\
\hline $\mathbf{7 .}$ & $\begin{array}{l}\text { Leaf width } \\
\text { (cm) }\end{array}$ & 6.9 & 13.0 & 5.5 & 2.0 & 1.1 & 3.2 & 36.7 & 16.92 & 10.25 & 12.8 \\
\hline $\mathbf{8 .}$ & $\begin{array}{l}\text { Actual leaf } \\
\text { area }\left(\mathrm{cm}^{2}\right)\end{array}$ & 80.1 & 295.0 & 7261 & 1916 & 1781.8 & 3697.7 & 48.2 & 30.24 & 20.99 & 30.0 \\
\hline
\end{tabular}

Note: MST: Mean square treatment, EV: environmental variance, GV: genetic variance, PV: phenotypic variance, $\mathrm{H}^{2}$ : heritability percentage, PCV: phenotypic cofficient of variance, GCV: genotypic cofficient of variance and GA: genetic advance

Fig.1 Genetic parameters for eight quantitative traits of 44 mulberry genotypes

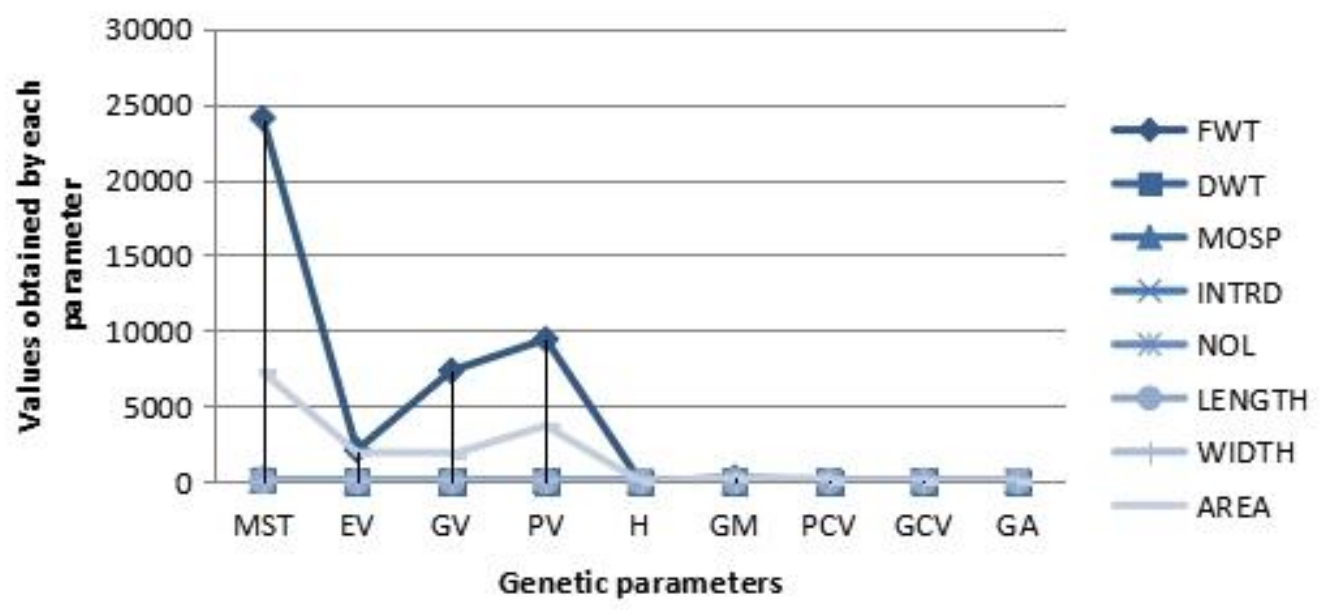

Tikader and Rao (2002) supported the current observations and highlighted the important of variability estimates for selection of parents in breeding programme. Similar results were also obtained by Puttarama et al., (2000), Siddiqui et al., (2003), Tikader et al., (2004), Banerjee et al., (2007) and Murthy et al., (2010) and stated that phenotypic variations were high as compared to 
genotypic variation. Maximum heritability percentage was observed for fresh leaf weight (77.9) whereas least for leaf width $(36.7 \%)$ which supports the earlier observations made by Tikader and Roy (1999) and Chikkalingaiah et al., (2008). High genetic advance was recorded for fresh leaf weight (63.7) followed by actual leaf area (30.0), leaf length (21.2), dry leaf weight (17.8), leaf width (12.8), moisture percentage (10.3), number of leaves per meter twig (3.9) and internodal distance (0.3). Similar kinds of results were also reported by Banerjee et al., (2008), Mallaikarjunappa et al., (2008) and Suresh et al., (2017).

High estimates of genetic gain coupled with high values of GCV depicted that these traits are under the control of additive genes and therefore phenotypic selection plays significant role in selection of parental material for improvement and development of promising genotypes by simple selection procedures.

\section{Acknowledgement}

The author is highly thankful to Dr. M. Iqbal Jeelani Bhat Assistant Professor (Statistics) Shere-Kashmir University of Agriculture Sciences and Technology-Jammu, for his valuable guidance and support for completion of this study.

\section{References}

Banerjee, R., Chowdhuri, S. R., Sau, H., Das, B. K., Ghosh, P. L., and Sarkar, A. (2008). Multiple yield traits for selection of mulberry (Morus spp.) germplasm for higher productivity. INDIAN J AGR SCI, 78(2): 142-145.

Banerjee, R., Roychowdhuri, S., Sau, S., Das, B. K., Ghosh, P., and Saratchandra, P. (2007).Genetic diversity and interrelationship among mulberry genotype.
JGG, 34(8): 691-697.

Chikkalingaiah., Chinnaswamy, K. P., Devi, G. T. and Venkatesh, M. 2008. Evaluation of mulberry germplasm for different growth parameters in Morus indica. International conference on trends in Seribiotechnology, March.27-29, Ananthapur, P.4.

Mallikarjunappa, R. S., Venkateshaiah, H. V., Rao, M. S. E., Anantharaman, M. N., and Bongale, U. D. (2008). Genetic variability and correlation studies in mulberry germplasm. IJS, 47(2): 226-229.

Murthy, B. C. K., Puttaraju, H. P., and Hittalmani, S. (2010). Genetic variability and correlation studies in selected mulberry (Morus spp.) germplasm accessions. Electron J Plant Breed, 1(3): 351-355.

Puttarama, N., Rangaiah, S., Govindan, R., Nehru, S.D., and Dandin, S.B. (2000). Genetic variability for leaf yield and quality traits in mulberry (Morus sp.). Environment and Ecology, 18(2): 295-298.

Siddiqui, A. A., Babu, L., and Khatri, R. K. (2003). Genetic variability in mulberry for foliar traits. Indian Journal of Forestry, 26(3): 217-219.

Suresh, K., Jalaja, S. K., Banerjee, R., and Trivedy, K. (2017). Genetic variability, correlation and path analysis in physiological and yield attributes in mulberry (Morus spp.). Journal of Crop and Weed, 13(1): 28-33.

Tikadar, A., and Roy, B. N. (1999). Genetic variability and character association in mulberry (Morus spp.). Indian Journal of Forestry, 22(2): 26-29.

Tikader, A. and Roy, A. 2002. Phenotypic variation in mulberry (Morus spp.) germplasm. Sericologia, 42(2): 221-233.

Tikader, A., Thangavelu, K., and Ananda, A. R. (2004). Characterisation and evaluation of mulberry (Morus spp.) Germplasm. IJS, 43(1): 106-110.

\section{How to cite this article:}

Suraksha Chanotra, Ramesh Kumar Bali and Kamlesh Bali. 2019. Estimation of Genetic Variability and Heritability in Selected Mulberry Germplasm Accessions (Morus spp.). Int.J.Curr.Microbiol.App.Sci. 8(02): 493-499. doi: https://doi.org/10.20546/ijcmas.2019.802.056 